\title{
On Lyrical Poetry of Wordsworth, a Poet of Nature
}

\author{
Xiaolin Huang, Feifei Pei, Changle Fu \\ Air Force Logistics College, Xuzhou, China \\ Email: sisi612@163.com
}

Received 15 July 2014; revised 17 August 2014; accepted 10 October 2014

Copyright (C) 2014 by authors and Scientific Research Publishing Inc.

This work is licensed under the Creative Commons Attribution International License (CC BY). http://creativecommons.org/licenses/by/4.0/

c) (i) Open Access

\begin{abstract}
William Wordsworth, one of the greatest poets in England, is known as the poet of nature. His poems took on greater significance in English literature. The purpose of this essay is to study his source of forming such a lyrical style and the process he expressed his ideal in singing highly of the nature to show my respect towards him.
\end{abstract}

\section{Keywords}

Nature, Lyrical Style, Romanticism

At the turn of the 18th and the 19th centuries, romanticism came to be the new trend in English literature. William Wordsworth, the representative poet of Romanticism, whose poems took on greater significance, brought a totally new and fresh stream of air to the European literary field. Wordsworth, the glittering star, is always shinning in English literature. His whole life had a close connection with nature- the permanent subject sung highly by human being. Wordsworth was called by Shelly "Poet of nature". He, too, called himself "A Worshiper of Nature". He held a firm faith that nature could enlighten the kindheartedness and universal brotherhood of human being, and only exist in harmony with nature where man could get true happiness. In his poems of nature he printed beautiful pictures full of the creation by the mighty God-mountains, rocks, rivers and trees. All of them revealed the poets genuine love towards the nature, the fervent enthusiasm of pursuing the truth of life. The purpose of this essay is to study his source of forming such a lyrical style and the process he expressed his ideal in singing highly of the nature to show my respect towards him.

Wordsworth's birth place was near to nature. Born in Cockermouth, just on the northern fringe of the English Lake district, he spent his childhood there. As a child, he often wandered among the fields and woods. At the age of 8, he was fed by one of his relatives who gave him simple food and shelter, but freedom of enjoying the nature. The Natural scenes and sounds gave his imagination wings and made him get to know the cottagers, shepherds, and solitary wanders that then entered his dreams and even his later poems. At the age of 14, Wordsworth 
was sent to school at Hawkshead in the beautiful lake district in northwestern England. There, the unroofed school of nature attracted him more than the classroom, and he learned more eagerly from flowers, hills and stars than from his books. Just as De Quinley said, "Wordsworth had his passion for nature fixed in blood. It was a necessity. And through his commerce with nature did he live and breathe”. The colors, scents, sounds, the blue of the sky, the sparkle of the sunlight on water, the sound and plumage of birds in nature deeply influenced Wordsworth's growth of genius. The great love for nature early cherished by the child was later expressed in his poetry.

In the poem "Lines Written in Early Spring", on an early spring morning, the poet walked in a small woods. Birds sang sweetly on the trees and groups of primrose blossom. The periwinkle climbed here and there coming into wreaths form.

"Through primrose tufts, in that green bower,

The periwinkle trailed its wreaths,

And' tis my faith that every flower

Enjoys the air it breathes

$\cdots$

The budding twigs spread out their fun,

To catch the breezy air:

And I must think, do all I can,

That there was pleasure there".

In this poem, Wordsworth was deeply impressed by the charming and fresh scenes in early spring. By vividly describing typical objects in nature such as "tufts, bower, wreaths, flower, air, budding twins" etc., we admire a calm while prosperous natural world. Here we cannot deny that nature and his own experience in childhood was the fountain of Wordsworth's latter literary creation.

Wordsworth is a master hand in depicting natural things. Quiet, beautiful, sweet, pleasure and so on are the most commonly seen words in his poems. There words stand out to reveal the poet's deep love and respect to nature just as we have interpreted above. To Wordsworth nature is an old friend remaining intimate even after long time parting. In addition to this, nature comes also as the source of energy, "And passing even into my purer mind, with tranquil restoration-feelings too of unremembered pleasure". "Even I'm tired of several years of social life, as soon as I return to nature, his quiet and peace power can make me restore my energy" (Averill, 1980).

The contemporary social background serves as the second reason why Wordsworth's lyrical poems make so much room for nature. After the Industrial Revolution, England was the scene of complicated social contradictions and changes. The bourgeoisie had become the ruling class. In order to make profit, they developed industry which ruined the purity and tranquility of nature. Living in the crowded and noisy society, Wordsworth felt greatly miserable. Only in nature, can he find beauty and purity going into his own thinking. Natural world is his ideal word.

The great neoclassic writers dealt with men as members of an organized, usually an urban, society; of this society the author regarded himself as an integral part, its highest standards were those he spoke for. As the worshiper of nature Wordsworth made a major departure in this respect. He described himself, in Peclude as "musing in solitude". And in almost all Wordsworth's poems, long or short, the words "single", "solitary", "by oneself", "alone" constitute a leitmotif; his imagination is released by the sudden appearance of a single figure or object, completely against an undifferentiated background. In such a lonely state Wordsworth got close to the nature. His mind and heart became pure and free from the bitterness and the trouble of the human society. Only can nature purify human's mind. Let's come into his spiritual world and share his enjoyment of nature in "Tinterm Abbey":

“These beauteous forms,

Through' a long absence, have not been to me

As is a landscape to a blind man's eye;

But oft' in lonely rooms, and mid the din

Of towns and cities, I have owed to them

In hours of weariness, sensations sweet 
Felt in the blood, and felt along the heart;

And passing even into my purer mind,

With tranquil restoration-feelings too”.

As we can see, though Wordsworth's poems including “Tintem Abbey” which are called "nature poetry” didn't describe the nature for its own sake. In fact they are meditative poems, in which the presented scene usually serves to raise an emotional problem or personal crisis. Their development and resolution constitute the organizing principle of the poem. As Wordsworth said in his prospectus to The Peclude, not only nature, but "the Mind of man" is "my haunt and the main region of my song”.

In other poems, we can see his communication with nature and her powerful effect upon his thoughts and emotions. The sight of the rainbow makes him moved in "My Heart Leaps Up", the hearing of the mountain echo provokes his philosophical contemplation in "The Echo", and the visit to the mountain inspires him to meditations of eternity in "The Simplon Pass". In "Composed Upon an Evening of Extraordinary Splendour and Beauty”, the poet was obviously struck by the unusual sight of an evening glow which so impressed him with its rare splendor and beauty.

Wordsworth also is much more than a mere reporter of surface beauties. Though Wordsworth's poems were imbued with the harmony, the sweetness and the peace of the nature, we can still find the great reflection of the tremendous social renovation. Through his meditation in his poems we can clearly see his attitude towards the great changes of the society and the newly appearance of the bourgeois during the declining of the feudal system.

Wordsworth loves nature as well as human being. He made the most proper combination between his love of man and love of nature in his works. He entrusted his love of man on the love of nature and in return, his love of natural scenery and the life of the people living in nature. He not only wrote so many poems but also developed his own outstanding theory on poetic creation. In the "Preface to Lyrical Ballads" he ever said. "Low and rustic life was generally chosen”, "to choose incidents and situations from common life”. Because "the condition, the essential passions of the heart find a better soil”. In a large number of his poems, Wordsworth revealed his true compassion and love for the sufferings of the poor and the unfortunate.

All the above is what the nature tells Wordsworth and what Wordsworth tells the readers through his natural poems. His poems and his theory of poetry have great significance in English literature. The lyrical style not only set a fresh example for the later poets, such as Byron, Shelley, Keats, but also influenced them greatly. Up to nowadays his principles of writing poems and the concept of poetry are still practical for today's writers. Many writers make their efforts to explore themselves, regarding their own thoughts as the only faith. According to their principle, "Without sense, an individual can not get to know the objects" (Guo, 1998). They think that feeling is the only object that exists. In this respect Wordsworth did better than them. Instead of closing himself into his own mental world, he put himself into the nature even into the universe, finding the peace, pleasure, purity and all the excellent things.

\section{References}

Averill, J. H. (1980). Wordsworth and the Poetry of Human Suffering. New York: Cornell University Press.

Guo, Q. Y. (1998). A Course in English Literature. Shijiangzhuang: He Bei Education Press. 
Scientific Research Publishing (SCIRP) is one of the largest Open Access journal publishers. It is currently publishing more than 200 open access, online, peer-reviewed journals covering a wide range of academic disciplines. SCIRP serves the worldwide academic communities and contributes to the progress and application of science with its publication.

Other selected journals from SCIRP are listed as below. Submit your manuscript to us via either submit@scirp.org or Online Submission Portal.
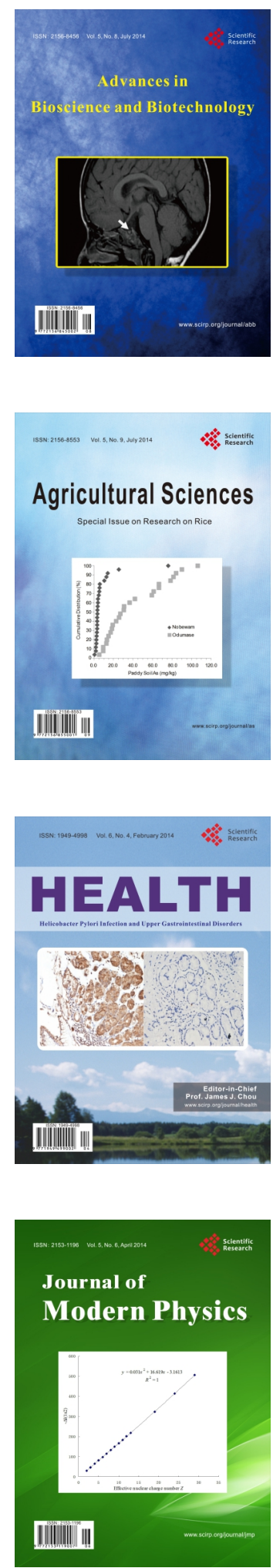
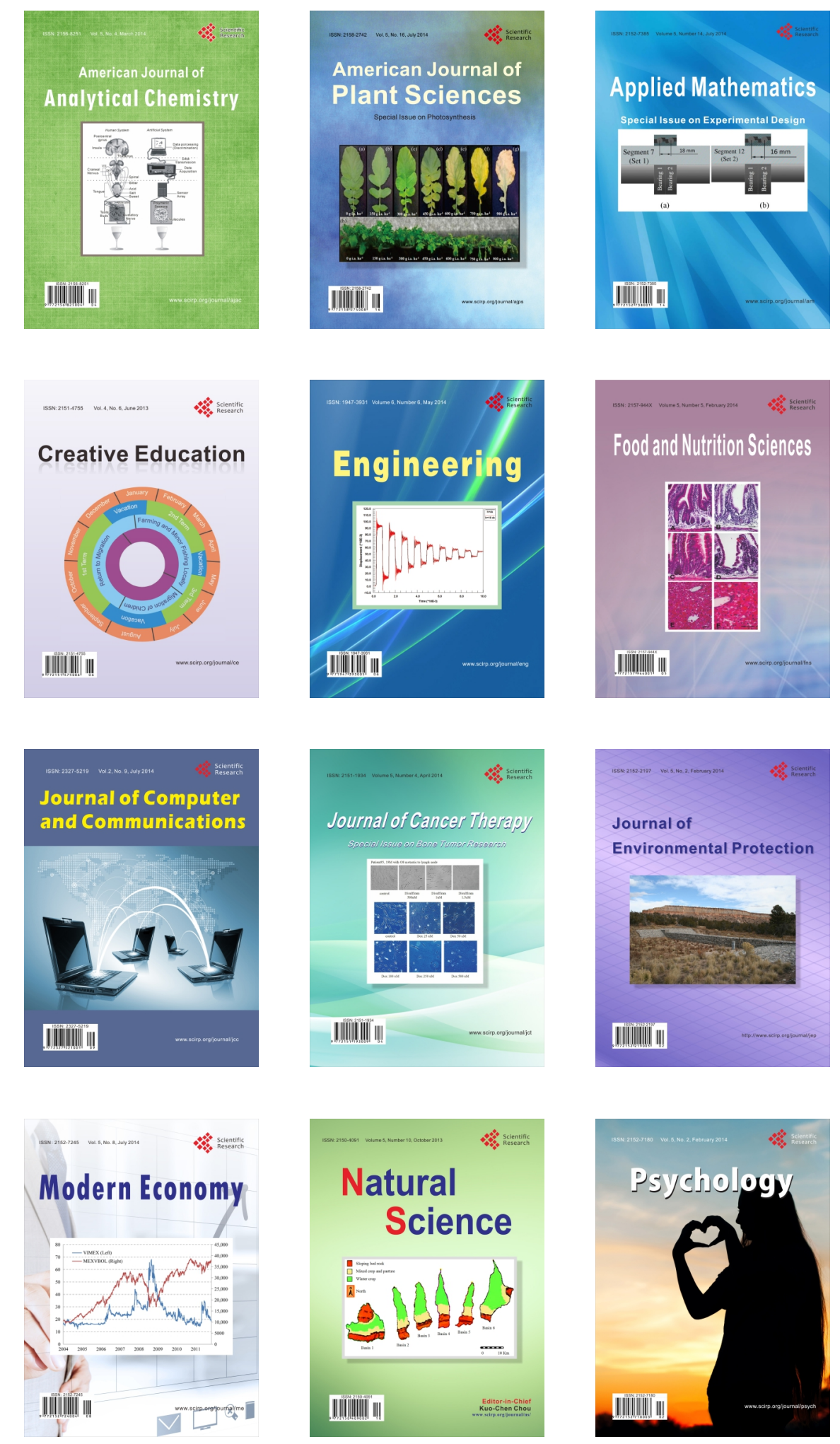